\title{
SOSIALISASI GERAKAN MASYARAKAT CERDAS MENGGUNAKAN OBAT DI DESA KUMAIN KECAMATAN TANDUN KABUPATEN ROKAN HULU
}

\author{
Asiska Permata Dewi ${ }^{1)}$, Isna Wardaniati'), Denia Pratiwi'), May Valzon ${ }^{2)}$ \\ 1) Prodi DIII Analis Farmasi dan Makanan, Fakultas Kedokteran dan Ilmu Kesehatan, \\ Universitas Abdurrab \\ 2)Program Studi Pendidikan Dokter, Fakultas Kedokteran dan Ilmu Kesehatan, \\ Universitas Abdurrab \\ email: asiska.permata@univrab.ac.id
}

\begin{abstract}
ABSTRAK
Telah dilakukan pengabdian kepada masyarakat tentang dagusibu (dapatkan, gunakan, simpan, dan buang) obat dengan benar di Desa Kumain, Kecamatan Rokan Hulu, Riau. Kegiatan ini dilakukan bertujuan untuk meningkatkan pemahaman masyarakat dalam penggunaan obat dan merupakan upaya bersama antara dosen dan masyarakat dalam rangka mewujudkan kepedulian, kesadaran, pemahaman dan keterampilan masyarakat dalam menggunakan obat secara tepat dan benar. Menteri Kesehatan RI pada tanggal 13 November 2015 mencanangkan "Gerakan masyarakat cerdas menggunakan obat" sebagai bagian dari upaya promotif, preventif dan pemberdayaan masyarakat dalam peningkatan penggunaan obat yang rasional. Kegiatan pengabdian masyarakat ini akan dilakukan dengan sosialisasi/ workshop dengan menggunakan metode ceramah, diskusi dan bimbingan. Hasil pengabdian menunjukkan bahwa pemahaman masyarakat Desa Kumain terhadap mendapatkan, menggunakan, menyimpan, dan membuang obat dengan benar meningkat.
\end{abstract}

Kata kunci: obat, rasional, cerdas menggunakan obat, dagusibu

\begin{abstract}
Has been done community service about dagusibu (get, use, save, and dispose) drugs correctly in Kumain Village, Rokan Hulu District, Riau. This activity is aimed to improve people's understanding in the use of drugs and is a joint effort between lecturers and the community in order to realize awareness, understanding, and community skills in using medicine properly and correctly. Minister of Health of the Republic of Indonesia on November 13, 2015 proclaimed "Movement of smart society using drugs" as part of efforts to promote, preventive and empower the community in increasing rational drug use. Community service activities will be conducted with socialization / workshop using lecture, discussion and guidance methods. The results of the devotion show that the Kumain Village community's understanding of obtaining, using, storing, and disposing of drugs is properly increased.
\end{abstract}

Key words: drugs, rasional, smart society using drugs, dagusibu. 


\section{PENDAHULUAN}

Kementrian Kesehatan Republik Indonesia pada tanggal 13 November 2015 mengadakan kegiatan sosialisasi gerakan masyarakat cerdas menggunakan obat (Gema Cermat). Kegiatan ini dilakukan bertujuan untuk meningkatkan pemahaman masyarakat dalam penggunaan obat. Permasalahan yang sering ditemukan di masyarakat adalah penggunaan obat bebas secara tidak tepat dan kurangnya pemahaman tentang cara menggunakan, menyimpan dan membuang obat dengan benar. Masalah lainnya adalah penggunaan antibiotik yang tidak tepat di masyarakat. Hal ini disebabkan masih kurangnya pemahaman masyarakat dan perilaku yang salah dalam penggunaan obat. Berdasarkan hasil riset kesehatan dasar (Riskesdas) 2013, menunjukkan bahwa 35,2\% rumah tangga menyimpan obat untuk swamedikasi (Kemenkes RI, 2013).

Penggunaan obat bebas (OTC) tanpa pengetahuan dan informasi memadai dapat menyebabkan masalah kesehatan baru, misalnya dosis berlebihan, waktu penggunaan obat tidak tepat, interaksi obat/penyalahgunaan obat, dan sebagainya. Selain itu, penggunaan antibiotika yang tidak tepat dan berlebihan, dapat meningkatkan kejadian antimicrobial resistance (AMR) atau resistensi bakteri terhadap antibiotika. Pemasalahan resistensi ini dapat meningkatkan angka mortalitas dan biaya pengobatan. Angka kematian masyarakat di Indonesia $>135.000$ kematian /tahun disebabkan oleh kasus infeksi.

Untuk mengatasi permasalahan tersebut, perlu dilakukan edukasi terhadap masyarakat. Gerakan Masyarakat Cerdas Menggunakan Obat (GeMaCerMat) ini merupakan upaya bersama antara pemerintah dan masyarakat melalui rangkaian kegiatan dalam rangka mewujudkan kepedulian, kesadaran, pemahaman dan keterampilan masyarakat dalam menggunakan obat secara tepat dan benar.

Sosialisasi GeMaCerMat saat ini akan dilaksanakan di Desa Kumain Kec. Tandun Kab. Rokan Hulu Sasaran kegiatan adalah kelompok masyarakat dan Ibu-ibu PKK dengan melibatkan dosen dan mahasiswa Universitas Abdurrab, organisasi profesi, dan stake holder terkait lainnya.

\section{Perumusan Masalah}

Permasalahan yang sering ditemukan di masyarakat adalah penggunaan obat secara tidak tepat dan kurangnya pemahaman tentang cara menggunakan, menyimpan dan membuang obat dengan benar. Selain itu, penyebab lain adalah pasien dengan pengetahuan yang salah akan cenderung menganggap wajib diberikan antibiotika dalam penanganan penyakit meskipun disebabkan oleh virus, misalnya flu, batuk-pilek, demam. Pasien dengan kemampuan finansial yang baik akan meminta diberikan terapi antibiotika yang paling baru dan mahal meskipun tidak diperlukan. Bahkan pasien membeli antibiotika sendiri tanpa peresepan dari dokter (self medication).

Dengan demikian, Menteri Kesehatan RI pada tanggal 13 November 2015 mencanangkan "Gerakan masyarakat cerdas menggunakan obat" sebagai bagian dari upaya promotif, preventif dan pemberdayaan masyarakat dalam peningkatan penggunaan obat yang rasional, sehingga dapat meningkatkan kualitas hidup masyarakat. Melalui gerakan ini diharapkan masyarakat dapat mendapatkan, menggunakan, meyimpan, dan membuang obat dengan benar. Selain itu, masyarakat hendaknya aktif mencari informasi dan bertanya kepada apoteker sebelum menggunakan obat. Dengan demikian, masalah kesehatan akibat kesalahan penggunaan obat dapat diminimalisir. Dalam kegiatan ini, diharapkan akan terwujud masyarakat desa Kumain Kecamatan Tandun Kabupaten Rokan Hulu cerdas dalam menggunakan obat. 


\section{TINJAUAN PUSTAKA}

Obat adalah sediaan atau paduan bahan-bahan yang siap digunakan untuk mempengaruhi atau menyelidiki sistem fisiologi atau keadaan patologi dalam rangka penetapan diagnosis, pencegahan, penyembuhan, pemulihan, peningkatan kesehatan dan kontrasepsi (Kemenkes RI, 2006).

Menurut World Health Organization (WHO), penggunaan obat secara rasional meliputi: Pasien menerima obat yang sesuai dengan kebutuhannya, periode waktu yang adekuat, harga yang terjangkau.

1. Kriteria penggunaan obat rasional adalah :

a. Tepat diagnosis

Obat diberikan sesuai dengan diagnosis. Apabila diagnosis tidak ditegakkan dengan benar maka pemilihan obat akan salah.

b. Tepat indikasi penyakit

Obat yang diberikan harus yang tepat bagi suatu penyakit.

c. Tepat pemilihan obat

Obat yang dipilih harus memiliki efek terapi sesuai dengan penyakit.

d. Tepat dosis

Dosis, jumlah, cara, waktu dan lama pemberian obat harus tepat. Apabila salah satu dari empat hal tersebut tidak dipenuhi menyebabkan efek terapi tidak tercapai.

1) Tepat Jumlah Jumlah obat yang diberikan harus dalam jumlah yang cukup.

2) Tepat cara pemberian

Cara pemberian obat yang tepat adalah Obat Antasida seharusnya dikunyah dulu baru ditelan. Demikian pula antibiotik tidak boleh dicampur dengan susu karena akan membentuk ikatan sehingga menjadi tidak dapat diabsorpsi sehingga menurunkan efektifitasnya.

3) Tepat interval waktu pemberian

Cara Pemberian obat hendaknya dibuat sederhana mungkin dan praktis agar mudah ditaati oleh pasien. Makin sering frekuensi pemberian obat per hari (misalnya 4 kali sehari) semakin rendah tingkat ketaatan minum obat. Obat yang harus diminum $3 \times$ sehari harus diartikan bahwa obat tersebut harus diminum dengan interval setiap 8 jam.

4) Tepat lama pemberian

Lama pemberian obat harus tepat sesuai penyakitnya masing-masing. Untuk Tuberkulosis lama pemberian paling singkat adalah 6 bulan, sedangkan untuk kusta paling singkat 6 bulan. Lama pemberian kloramfenikol pada demam tifoid adalah $10-14$ hari.

e. Tepat penilaian kondisi pasien

Penggunaan obat disesuaikan dengan kondisi pasien, antara lain harus memperhatikan: kontraindikasi obat, komplikasi, kehamilan, menyusui, lanjut usia atau bayi.

f. Waspada terhadap efek samping

Obat dapat menimbulkan efek samping, yaitu efek tidak diinginkan yang timbul pada pemberian obat dengan dosis terapi, seperti timbulnya mual, muntah, gatalgatal, dan lain sebagainya.

g. Efektif, aman, mutu terjamin, tersedia setiap saat, dan harga terjangkau

Untuk mencapai kriteria ini obat dibeli melalui jalur resmi. 
h. Tepat tindak lanjut (follow up)

Apabila pengobatan sendiri telah dilakukan, bila sakit berlanjut konsultasikan ke dokter.

i. Tepat penyerahan obat (dispensing)

Penggunaan obat rasional melibatkan penyerah obat dan pasien sendiri sebagai konsumen. Resep yang dibawa ke apotek atau tempat penyerahan obat di Puskesmas akan dipersiapkan obatnya dan diserahkan kepada pasien dengan informasi yang tepat.

j. Pasien patuh terhadap perintah pengobatan yang diberikan

Ketidakpatuhan minum obat terjadi pada keadaan berikut :

- Jenis sediaan obat beragam

- Jumlah obat terlalu banyak

- Frekuensi pemberian obat per hari terlalu sering

- Pemberian obat dalam jangka panjang tanpa informasi

- Pasien tidak mendapatkan informasi yang cukup mengenai cara menggunakan obat

- Timbulnya efek samping (DepKes RI, 2008).

2. Penggolongan Obat

Obat dapat dibagi menjadi 4 golongan, yaitu:

1. Obat bebas. Obat bebas adalah obat yang dijual bebas di pasaran dan dapat dibeli tanpa resep dokter. Tanda khusus pada kemasan dan etiket obat bebas adalah lingkaran hijau dengan garis tepi berwarna hitam. Contoh : Parasetamol.

2. Obat Bebas Terbatas. Obat bebas terbatas adalah obat yang sebenarnya termasuk obat keras tetapi masih dapat dijual atau dibeli bebas tanpa resep dokter, dan disertai dengan tanda peringatan. Tanda khusus pada kemasan dan etiket obat bebas terbatas adalah lingkaran biru dengan garis tepi berwarna hitam. Contoh : CTM.

3. Obat Keras dan Psikotropika. Obat keras adalah obat yang hanya dapat dibeli di apotek dengan resep dokter. Tanda khusus pada kemasan dan etiket adalah huruf $\mathrm{K}$ dalam lingkaran merah dengan garis tepi berwarna hitam.Contoh : Asam Mefenamat. Sedangkan obat psikotropika adalah obat keras baik alamiah maupun sintetis bukan narkotik, yang berkhasiat psikoaktif melalui pengaruh selektif pada susunan saraf pusat yang menyebabkan perubahan khas pada aktivitas mental dan perilaku. Contoh : Diazepam, Phenobarbital.

4. Obat narkotika. Obat narkotika adalah obat yang berasal dari tanaman atau bukan tanaman baik sintetis maupun semi sintetis yang dapat menyebabkan penurunan atau perubahan kesadaran, hilangnya rasa, mengurangi sampai menghilangkan rasa nyeri dan menimbulkan ketergantungan. Contoh : Morfin, Petidin.

3. Cara penggunaan obat

1. Penggunaan obat tidak untuk pemakaian secara terus menerus.

2. Gunakan obat sesuai dengan anjuran yang tertera pada etiket atau brosur.

3. Bila obat yang digunakan menimbulkan hal-hal yang tidak diinginkan, hentikan penggunaan dan tanyakan kepada Apoteker dan dokter.

4. Hindarkan menggunakan obat orang lain walaupun gejala penyakit sama.

5. Untuk mendapatkan informasi penggunaan obat yang lebih lengkap, tanyakan kepada Apoteker (Muchid, 2006). 


\section{METODE PELAKSANAAN}

Kegiatan pengabdian masyarakat ini akan dilakukan dengan sosialisasi/ workshop dengan menggunakan metode ceramah, diskusi dan bimbingan. Metode ceramah dilakukan dengan memberikan materi terkait tentang gerakan masyarakat cerdas menggunakan obat. Selanjutnya, dilanjutkan dengan diskusi/tanya jawab dengan peserta terkait bagaimana cara penggunaan obat yang rasional. Metode lanjutan setelah selesai acara berlangsung, akan diselenggarakan bimbingan/ konseling gratis bagi masyarakat yang mengalami masalah dalam cara penggunaan obat yang rasional melalui sms ke kontak kami.

\section{HASIL DAN PEMBAHASAN}

Kegiatan pengabdian ini dilaksanakan dalam bentuk penyuluhan dengan metode ceramah, diskusi dan bimbingan tentang DaGuSiBu (Dapat, Gunakan, Simpan, Buang) obat yang baik dan benar. Dagusibu juga merupakan salah satu kegiatan aplikatif dalam rangka GeMaCerMat (Gerakan Masyarakat Cerdas Menggunakan Obat).

Metode ceramah dilakukan dengan memberikan materi bagaimana mendapatkan obat yang benar yaitu membeli obat di apotik atau sumber-sumber terpecaya, menggunakan obat dengan baik dan benar sesuai dengan penggunaaan obat rasional yaitu tepat diagnosis, tepat indikasi penyakit, tepat tepat pemilihan obat, tepat dosis, tepat penilaian kondisi pasien, waspada akan efek samping yang mungkin terjadi, efektif, aman, mutu terjamin, tersedia setiap saat, tepat tindak lanjut, tepat penyerahan obat, kepatuhan pasien.

Peserta memahami bagaimana mereka harus menyimpan obat dengan baik dan benar agar tidak merusak kualitas obat sehingga tidak menimbulkan efek yang merugikan, peserta juga diajarkan bagaimana membuang obat dengan baik dan benar agar selanjutnya tidak digunakan oleh pihak-pihak yang tidak bertanggung jawab. Peserta diberi pengetahuan tentang penggolongan obat di Indonesia dan penandaannya yang terdapat pada kotak kemasan

Kegiatan penganbdian ini berjalan lancar, peserta terdiri dari ibu-ibu rumah tangga yang biasanya juga mereka ada menyimpan obat di dalam rumah. Banyaknya pertanyaan yang diajukan menunjukkan peserta sangat antusias mendapatkan materi Dagusibu dan Gema Cermat apalagi hal ini terkait dengan isu-isu yang beredar di masyarakat perihal penyalahgunaan obat atau adanya obat illegal. Selanjutnya metode bimbingan berkelanjutan dilakukan dengan cara dibuka call center atau pengaduan masyarakat terkait dengan penggunaan obat.
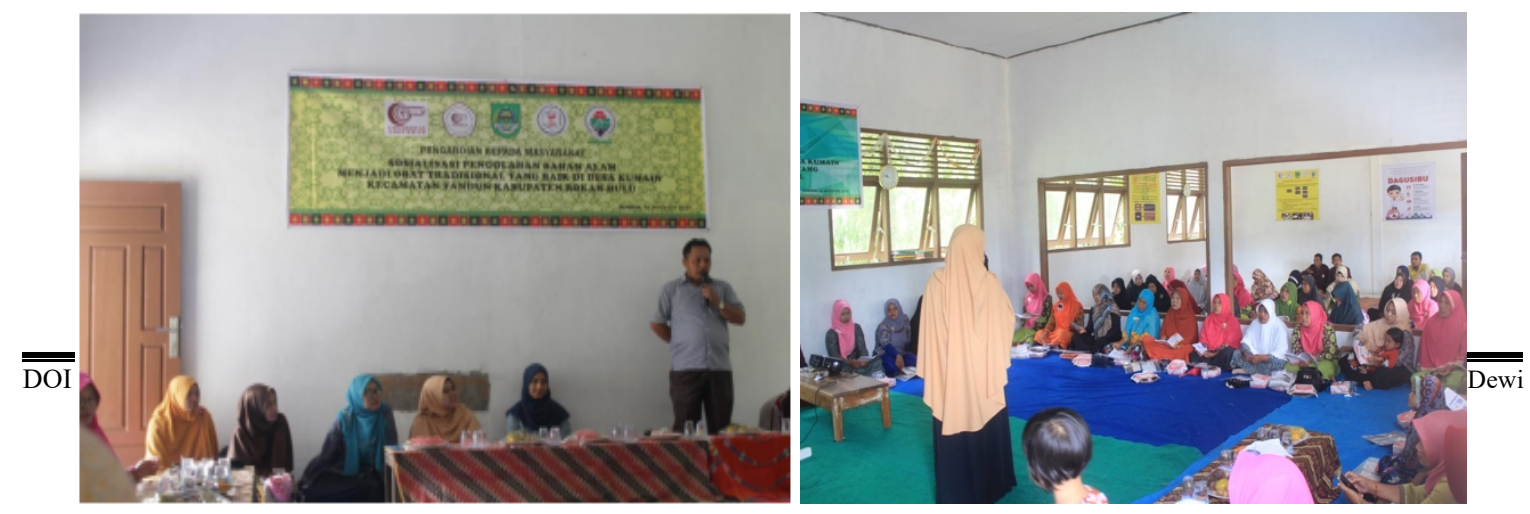
Gambar 1. Pembukaan

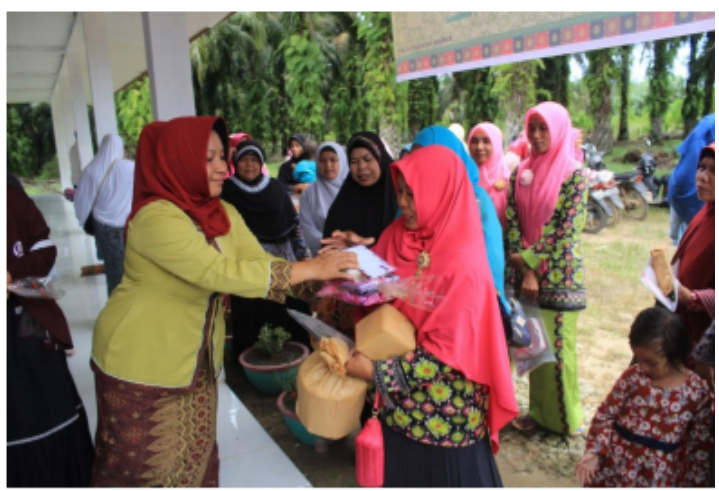

Gambar 3. Pembagian dorprise
Gambar 2. Penyampaian materi

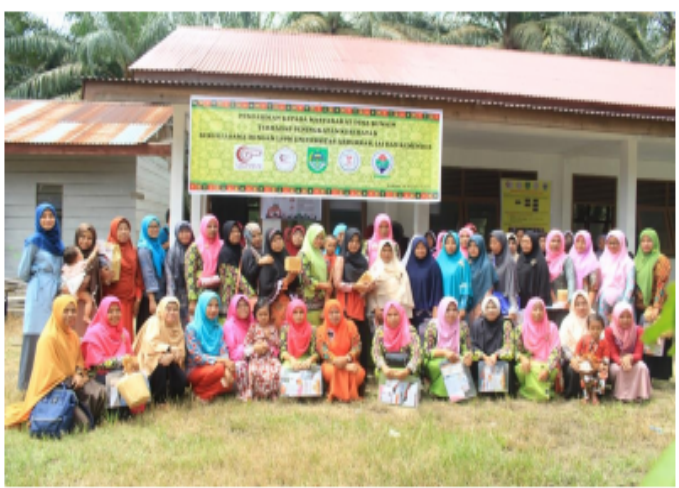

Gambar 4. Foto bersama

Gambar di atas merupakan foto-foto kegiatan pengabdian kepada masyarakat yang telah dilakukan. Kegiatan diawali dengan pembukaan oleh kepala desa Kumain, kemudian dilanjutkan dengan penyampaian materi, sesi tanya jawab, dan pembagian dorprise bagi peserta yang bertanya kepada pengabdi. Akhir kegiatan ini dilakukan foto bersama antara semua pengabdi dengan peserta kegiatan.

\section{KESIMPULAN}

Berdasarkan kegiatan yang dilakukan dapat disimpulkan bahwa kegiatan pengabdian ini dapat meningkatkan pemahaman masyarakat Desa Kumain tentang DaGuSiBu dan Gema Cermat, sehingga untuk selanjutnya kualitas kehidupan masyarakat khususnya Desa Kumain Kecamatan Tandun Kabupaten Rokan Hulu dan masyarakat Indonesia pada umumnya akan meningkat.

\section{DAFTAR PUSTAKA}

[5]. Departemen Kesehatan Republik Indonesia Direktorat Jendral Bina Kefarmasian dan Alat Kesehatan. 2008. Materi Pelatihan Peningkatan Pengetahuan dan Keterampilan memilih Obat Bagi Tenaga Kesehatan. Jakarta.

[6]. Keputusan Menteri Kesehatan Republik Indonesia No. 189/MENKES/SK/III/2006 Tentang Kebijakan Obat Tradisional. Jakarta.

[7]. Kementrian Kesehatan Republik Indonesia Badan Penelitian dan Pengembangan Kesehatan. 2013. Riset Kesehatan Dasar. Jakarta.

[8]. Muchid, A. 2006. Pedoman Penggunaan Obat Bebas Dan Bebas Terbatas. Direktorat Bina Farmasi Komunitas Dan Klinik ,Bina Kefarmasian Dan Alat Kesehatan Departemen Kesehatan. Jakarta. 